\title{
Strategi Pengembangan Kualitas Lingkungan Hidup Melalui Penerapan SMK3 di Tempat Pembuangan Sampah Akhir
}

\author{
Yuan Badrianto ${ }^{1)} \mid$ Muhamad Ekhsan ${ }^{2)}$ \\ 1,2) Universitas Pelita Bangsa \\ yuan.badrianto@pelitabangsa.ac.id | muhamad.ekhsan@pelitabangsa.ac.id
}

\begin{abstract}
Abstrak: Sampah merupakan salah satu yang dihasilkan dari sisa kegiatan masyarakat dimana bagi sebagian orang sulit untuk dikelola dan menjadi masalah yang tidak bisa dihindari oleh warga. Pertambahan jumlah penduduk menyebabkan peningkatan aktivitas yang artinya juga dapat meningkatkan jumlah indeks sampah, penumpukan sampah di tempat pembuangan sampah akhir akan berhubungan dengan kualitas hidup masyarakat sekitarnya. Pengelolaan sistem keselamatan dan kesehatan kerja merupakan salah satu upaya preventif yang dilakukan dalam meminimalisasi dan menghilangkan penyakit akibat kerja ataupun kecelakaan akibat kerja. Ekonomi merupakan salah satu faktor yang mempengaruhi kesejahteraan dan kehidupan masyarakat. Tidak dapat dipungkiri bahwa keberadaan tempat pembuangan sampah telah memberikan dampak terhadap perekonomian beberapa masyarakat sekitar. Pada kenyataannya banyak masyarakat yang mengeluhkan penyakit yang sering muncul setelah adanya tempat pembuangan sampah akhir. Pengelolaan sampah dan fasilitas kebersihan yang kurang baik menyebabkan kualitas lingkungan menjadi buruk demikian juga dengan Desa Burangkeng. Hasil penelitian dapat disimpulkan bahwa Desa Burangkeng merupakan desa tempat pembuangan akhir sampah yang memerlukan perhatian khusus dari pemerintah terutama dari segi kesehatan masyarakat dan kondisi lingkungan. Adanya organisasi Prabu sebagai pemersatu warga belum dapat berperan secara maksimal terutama jika berhubungan dengan kebijakan pemerintah meskipun mereka telah berupaya untuk menjadi jembatan aspirasi sekaligus sebagai referensi akan informasi dan pengetahuan warga mengenai kondisi lingkungan serta dampak dari TPA.
\end{abstract}

Kata Kunci: Pendidikan dan Pelatihan, Kualitas Lingkungan Hidup, Pembuangan Sampah

\section{Pendahuluan}

Sampah secara umum merupakan masalah bagi lingkungan masyarakat, terlebih masyarakat urban yang hidup dengan kepadatan penduduk serta taraf pendidikan yang relatif lebih tinggi tentunya perlu lebih memperhatikan dan menjadi contoh dalam pengelolaan dan penanggulangan akan sampah. Selain itu lahan juga berhubungan erat dengan manusia dan lingkungan (Setyawati, 2008). Harapan ini ternyata terbalik jika kita melihat pada beberapa tempat pembuangan sampah akhir yang mana perlu diketahui bahwa tempat tersebut masih tidak jauh dari Jakarta yang menjadi ibu kota Indonesia. Salah satu desa tempat pembuangan sampah akhir (TPA) adalah Desa Burangkeng, sebuah desa yang berlokasi tidak jauh dari pusat kota Bekasi, yang mana kita ketahui bahwa Bekasi merupakan tempat berdirinya pabrik dan menjadi kawawsan industri terbesar di Asean (Yuniarti \& Samariansyah, 2014). Artinya geliat kehidupan masyarakat dengan penghasilan minimal UMR dan para lulusan universitas berbondong-bondong hijrah mencari penghidupan, seyogyanya menjadi kota terdepan dalam pembangunan lingkungan. 
Burangkeng, jika dilihat secara kasat mata memang perlu perhatian, selain menggunungnya sampah, aroma yang relatif dapat dicium dalam kondisi iklim tertentu, juga keadaan masyarakat yang masih belum seluruhnya berkembang serta beberapa potensi yang kurang digalakan dapat menghambat progres peningkatan index pembangunan manusia yang saat ini masih belum naik secara signifikan, Indeks pembangunan manusia merupakan salah satu indikator untuk mengetahui pembangunan ekonomi yang mengukur taraf kualitas fisik dan non fisik penduduk, yaitu kesehatan, tingkat pendidikan dan indikator ekonomi (Suliswanto, 2010). Data menunjukan lambatnya pertumbuhan Indeks Pembangunan Manusia (IPM) tahun 2020 dibanding tahun-tahun sebelumnya. IPM Indonesia tahun 2020 adalah sebesar 71,94 atau tumbuh 0,03 persen (meningkat 0,02 poin) dibandingkan capaian tahun sebelumnya (BPS, 2020)

Salah satu penunjang keberhasilan dari pembangunan suatu negara adalah dengan meningkatkan pembangunan suatu daerah (Sutrisno, 2009), seperti halnya dengan Desa Burangkeng, desa ini terletak di kecamatan Setu Kabupaten Bekasi Provinsi Jawa Barat. Sebagian besar penduduk desa Burangkeng saat ini sebagai buruh pabrik sejak era industri berkembang di Cikarang, namun banyak juga diantara penduduk sekitar yang menjadi petani, beternak dan pengais sisa sampah di tempat pembuangan sampah akhir, informasi yang didapatkan dari salah seorang pekerja di sana ada sekitar 200 penduduk yang mengais sampah tiap harinya di pembuangan sampah akhir Burangkeng

Burangkeng memiliki potensi alam yang cukup baik hal ini dapat dilihat adanya sawah dan tanah lapang yang masih terbentang diantara gunungan-gunungan sampah, namun sayangnya generasi muda yang masih produktif lebih senang beralih profesi sebagai karyawan atau buruh harian di pabrik, bahkan beberapa diantaranya lebih memilih berpindah ke pusat kota, menyewa kontrakan agar lebih dekat dengan tempat kerja atau perusahaan, semua itu memang menjadi pilihan antara pindah atau menetap di Desa Burangkeng dan beradaptasi dengan dampak TPA yang ditimbulkan .

Para pemuda di Burangkeng memiliki sebuah ikatan organisasi yang cukup solid yang bernaung dalam sebuah organisasi bernama Persatuan Pemuda Burangkeng Peduli Lingkungan (Prabu). Mereka memiliki program kerja untuk peningkatan kualitas hidup masyarakat Burangkeng yang terkena dampak secara signifikan dari polusi pembuangan sampah yang mereka rasakan melalui polusi air dan polusi udara. Program yang mereka gagas diantaranya adalah membantu melakukan monitoring pembuangan sampah yang diangkut oleh truk yang harus sesuai dengan prosedur keselamatan dan kesehatan lingkungan seperti penggunaan alat pelindung diri dan hal terpenting adalah menutup timbunan sampah yang diangkut dalam truk yang sering tercecer di tengah jalan. Selain itu para pemuda juga berusaha memberikan edukasi semampu mereka kepada para masyarakat mengenai resiko kerja dari mengais sampah, kendati demikian mereka merasa edukasi ini masih belum maksimal karena belum dilakukan pelatihan secara formal dan berkesinambungan.

Menurut Rhido yang menjadi salah seorang aktivis Prabu, masih banyak sekali potensi yang perlu digali di Desa Burangkeng, potensi alam dan lingkungan serta potensi dari SDM yang ada, seyogyanya pemerintah memberikan perhatian dan monitoring secara langsung akan konsidi TPA Burangkeng agar lebih cepat dalam peningkatan potensi SDM tersebut. Menurut 
Rhido saat ini konsistensi para pekerja dalam penggunaan alat pelindung diri (APD) masih harus ditingkatkan, kendati sudah diberikan APD namun karena tidak terbiasa ataupun kurangnya kesadaran dari masyrakat yang mengais sampah, terkadang tidak menggunakan APD yang sesuai.

Fenomena lain yang menjadi perhatian dari peneliti adalah informasi dari salah seorang warga yang pernah menjadi ketua masyarakat mengenai kekhawatiran akan kondisi pekerja dan masyarakat yang rentan terdampak dari TPA ini seperti penyakit kulit serta paparan polusi dari udara yang busuk saat truk melintas, selain itu peneliti juga melihat kondisi jalanan yang sempit jika terjadi pertemuan dua truk sampah, serta menggunungnya sampah di samping pemukiman warga yang tentu saja menimbulkan resiko longsor dan bahaya tertimbun, selain itu adalah kondisi air yang rasanya kurang sesuai dengan air di lingkungan lain.

Warga mengeluhkan akan Sistem Manajemen Keselamatan dan Kesehatan Kerja yang seharusnya dilakukan lebih baik oleh pemerintah atau pengelola setempat guna meningkatkan kualitas hidup yang lebih baik bagi seluruh warga Burangkeng. Aspirasi atau keluhan masyarakat Desa Burangkeng diwakilkan oleh ketua organisasi Prabu Bapak Carsa Hamdani yang berpendapat bahwa bukan hanya dengan pemberian santunan uang bau yang pada implementasinya juga kurang konsisten, namun yang masyarakat perlukan adalah perlu terobosan ide dan cara yang modern dalam pengelolaan sampah Burangkeng agar warga sekitar tidak terdampak dari polusi udara yang bau, lalat yang bertebaran dan hinggap di makanan, kondisi air yang kurang layak dan ramainya transportasi angkutan sampah.

Berbicara tentang pengelolaan modern, menurut Bapak Sofi sebagai kepala TPA Burangkeng 2021 telah mengupayakan bekerja sama dengan perusahaan untuk membantu dalam pengelolaan sampah yang akan dipadatkan menggunakan alat briket, menurut beliau upaya kerja sama ini sudah dibentuk dalam sebuah proposal yang minim budget dan telah ditembuskan ke pemerintah pusat, namun sayangnya belum ada realisasi atau tanggapan mengenai proposal tersebut.

Masyarakat dan pengelola TPA menyadari bahwa kualitas hidup di lingkungan Desa Burangkeng tidak lebih baik dengan adanya TPA disana bahkan banyak yang mengeluhkan akan penurunan kualitas hidup yang dirasakan diantarnya adalah kualitas air, kualitas udara, dan kualitas lingkungan hidup yang bersih.

\section{Realisasi Kegiatan}

Penelitian ini adalah penelitian kualitatif, data yang didapatkan melalui wawancara dan melakukan observasi di lapangan yang dalam hal ini adalah tempat pembuangan sampah akhir Desa Burangkeng. Wawancara dilakukan kepada beberapa warga yang terpilih seperti ketua organisasi, mantan kepala dusun dan kepala pengelola TPA. Selain wawancara metode penelitian ini juga mengkaji literasi yang ada. Wawancara merupakan percakapan dimana pertanyaan -pertanyaan diberikan oleh pewawancara direspon atau dijawab oleh orang yang diwawancarai (Basrowi, 2008). Adapun observasi merupakan aktifitas dalam mencatat suatu gejala dengan bantuan instrument untuk tujuan ilmiah ataupun tujuan tujuan lain (Denzin \& Lincoln, 2009). Berdasarkan dari hasil wawancara, observasi dan data yang didapatkan maka diolah dalam bentuk narasi sehingga penelitian ini diselesaikan. 


\section{Kondisi Ekonomi Masyarakat Burangkeng}

Perekonomian salah satu faktor yang dapat mempengaruhi terhadap kesejahteraan dan kehidupan masyarakat. Tidak dapat dipungkiri dengan adanya TPA berdampak pada perekonomian bagi beberapa masyarakat sekitar. Sebelum adanya TPA kondisi perekonomian masyarakat Desa Burangkeng masih dalam konsisi yang cukup baik dimana sebagain besar masyarakat dapat bekerja bertani, beternak dan generasi $\mathrm{Y}$ atau $\mathrm{Z}$ bekerja di perusahaan dengan pendapatan upah minimum regional. Warga di Desa Burangkeng juga sudah cukup sejahtera, dimana mereka mampu menyekolahkan anak-anaknya sampai tingkat sekolah menengah atas bahkan ada yang sampai perguruan tinggi.

Desa Burangkeng memiliki produksi daerah pada sektor pertanian berupa hasil sayur mayur yang dapat mencukupi kehidupan, beberapa penduduk memelihara ternak untuk di jual dan ada beberapa usaha kecil menengah berupa kios, bengkel dan pabrikasi. Dengan adanya TPA beberapa benduduk memanfaatkan untuk mengais rezeki disela-sela beternak atau aktifitas lain, ada pula yang kreatif mengepulkan barang yang bisa di daur ulang seperti plastik, penduduk lain memanfaatkan dengan membuka warung kecil untuk memenuhi kebutuhan para pekerja seperti warung kopi, warung nasi, jualanan minuman dan lain sebagainya.

\section{Kondisi Kesehatan Desa Burangkeng}

Kondisi kesehatan masyarakat Burangkeng memang tidak terlihat buruk jika kita tidak malakukan observasi secara langsung, jika menelisik lebih jauh sebetulnya banyak masyarakat yang mengeluhkan adanya penyakit-penyakit yang sering timbul semenjak adanya TPA di Burangkeng. Masyarakat juga mengeluhkan banyaknya lalat yang betebaran serta bau busuk saat truk sampah yang melintas, lalat-lalat tersebut hinggap pada ceceran air sampah dan membawa kotoran kepada makanan yang dikonsumsi oleh masyrakat sekitar sehingga beberapa dari masyarakat mengalami penyakit diare. Berikut adalah informasi mengenai kondisi kesehatan dan penyakit yang sering dialami oleh masyarakat Burangkeng:

a) Masyarakat merasakan adanya perbedaan dari kondisi air di Desa Burangkeng, terutama pada musim hujan dimana banyak warga yang mengalami gatal-gatal kulit menurut mereka hal ini disebabkan serapan air dari gunungan sampah menjalar ke air warga yang mengandalkan air tanah untuk kebutuhan hidup mereka.

b) Mayarakat awalnya mengeluh mual dengan adanya hilir mudik truk sampah, namun karena saat ini, mereka sudah sedikit terbiasa dan dapat beradaptasi dengan aroma tersebut meskipun tetap merasa terganggu

c) Penyakit lain yang dikeluhkan warga adalah seringnya mengalami diare, hal ini dapat terjadi dari konsumsi air yang tidak sehat atau adanya bakteri yang dibawa oleh lalat yang hinggap pada makanan yang terkonsumsi oleh warga.

d) Sebagai mana kita ketahui bawa sampah akan mengalami pembusukan dan pembusukan ini akan menghasilkan gas metan, gas $\mathrm{H} 2 \mathrm{~S}$ yang berbau busuk yang sifatnya racun bagi tubuh sehingga secara estetis tidak dapat diterima oleh tubuh dan dapat mengakibatkan ganguan penciuman dan pernafasan bagi sebagian warga.

Sampah yang menumpuk tentunya akan memberi dampak buruk dan berpengaruh terhadap kesehatan lingkungan dan tubuh, berikut adalah table penyakit akibat dari bawan sampah: 
Tabel 1. Penyakit Bawaan Sampah

\begin{tabular}{c}
\hline Nama Penyakit Bawaan lalat : \\
\hline Dysenteriterie basillaris, \\
Dysenteriterie amoebica, \\
Typhus abdominalis, \\
Cholera, \\
Ascariasis, \\
Ancylostomiasis. \\
\hline Nama Penyakit Bawaan Tikus : \\
Pest, \\
Leptospirosis, \\
Icterohaemorrhagica. \\
Rat bite fever \\
Keracunan \\
Metan. \\
Carbon Monoxida, \\
Hydrogen sulfide, \\
Logam berat, dst.
\end{tabular}

Sumber: (Soemirat, 2006)

\section{Kondisi Lingkungan Desa Burangkeng}

Selain kesehatan masyarakat hal yang tidak kalah penting adalah lingkungan desa Burangkeng yang perlu diperhatikan, secara umum mayoritas masyarakat Desa Burangkeng adalah sebagai petani, peternak sehingga mereka tidak memiliki asuransi kesehatan yang cukup layak, belum seluruhya memilki BPJS selain itu jarak menuju ke rumah sakit umum dirasa terlalu jauh. Pengelolaan sampah yang kurang baik, serta sarana penunjang untuk kebersihan yang belum maksimal, membuat lingkungan Desa Burangkeng masih memerlukan perhatian. Kita dapat melihat adanya tumpukan sampah di halaman rumah warga sekitar serta gunungan sampah merupakan fenomena yang akrab dapat dilihat di TPA Burangkeng, hal ini tentunya bukan lingkungan yang sehat untuk membesarkan para buah hati mereka yang tumbuh berkembang disana.

Kondisi yang paling menghawatirkan dari lingkungan TPA Burangkeng adalah gunugan sampah yang menjulang. Pengikisan ataupun runtuhan yang kerap muncul dikhawatirkan akan menimbun rumah atau pemukiman masyarakat yang tinggal disana. Kehawatiran ini tentunya dirasakan oleh warga sekitar namun mereka tidak punya pilihan untuk berpindah tempat tinggal dikarenakan tidak adanya fasilitas pengganti yang diberikan dan adanya rasa kepemilikian yang tinggi terhadap asset pribadi serta aspek psikologis lain yang menaham mereka untuk berpindah seperti rasa betah dan keterbiasaan. 

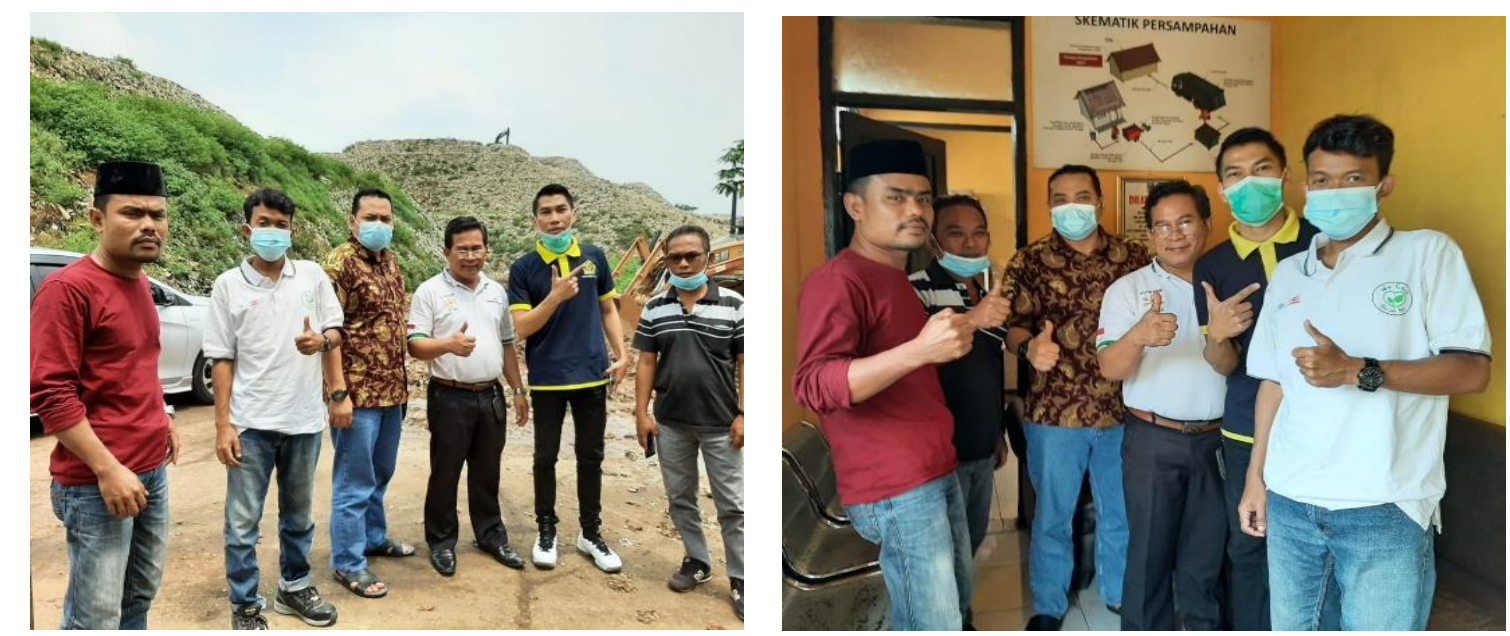

Gambar 1. Diskusi SMK3 Bersama Pengelola dan Warga Burangkeng

\section{$\underline{\text { Hasil }}$}

Desa Burangkeng merupakan desa tempat pembuangan sampah akhir yang memerlukan perhatian khusus, karena potensi di Desa ini masih belum terperhatikan dengan baik. Warga Desa Burangkeng memiliki sikap kerjasama warga yang baik, penerimaan dan sikap gotong rotong warga yang tentunya menjadi modal jika diarahkan pada peningkatan produktivitas, selain itu jika melihat banyaknya generasi produktif, seharusnya masyarakat lebih mampu dibina dan diberdayakan untuk pembangunan desa, seperti hasil dari pengepul yang seharusya dapat dikelola oleh masyarakat sekitar. Adanya komunitas dan organisasi Prabu juga menjadi potensi pemersatu pemuda dan warga sekitar, pemikiran yang kritis dan membangun diharapkan dapat meningkatakan kualitas hidup dari Desa Burangkeng.

Resiko yang dapat dialami oleh Desa Burangkeng lebih kepada kondisi lingkungan yang berbahaya, kondisi pencemaran air dan udara serta buruknya penanganan ceceran sampah berpotensi menimbulkan penyakit dan menurunkan kualitas hidup warga, selain itu gunungan sampah juga menimbulkan potensi bahaya longsor dan menimbun pemukiman penduduk. Berikut adalah hasil observasi dan strategy yang digalakan oleh Prabu:

a) Meningkatkan pemantauan akan muatan truk dan pengendara yang memang berpotensi melanggar prosedur

b) Memberikan himbauan kepada masyarakat agar menjaga lingkungan serta meningkatkan imunitas tubuh

c) Membantu menyampaikan aspirasi warga untuk disampaikan kepada pengelola sampah serta melakukan monitoring.

d) Bekerja sama dengan oragnisasi lain untuk melakukan pembinaan dan pengadaan pelatihan-pelatihan keterampilan dan kesehatan guna memunculkan potensi desa dan meningkatkan kualitas hidup.

Observasi yang telah kami lakukan menunjukkan ada beberapa potensi kecelakaan kerja dan penyakit akibat kerja pada sistem pengangkutan dan penimbunan sampah rumah tangga di TPA Burangkeng yang menunjukkan masih sangat perlu dibangun mengenai pengetahuan dan skill yang berhubungan dengan K3 dan Lingkungan (K3L). Hasil identifikasi menunjukkan, bahwa penerapan K3L pada Sistem Pengangkutan Sampah Rumah Tangga di TPA Burangkeng 
hanya berupa upaya dalam pencegahan kecelakaan kerja dengan dukungan adanya rambu rambu lalu lintas dan alat pelindung diri, sedangkan penerapan K3L masih yang belum maksimal, kurangnya sosilisasi dan himbauan-himbauan K3L sehingga masih memerlukan program dan pengembangan di lingkungan yang berhubungan dengan K3L.

Berikut adalah strategy pengembangan kualitas hidup melalui pendekatan penerapan $\mathrm{K} 3 \mathrm{~L}$ dalam program pelatihan yang direncakan oleh Prabu yaitu:

1) Pelatihan dasar keselamatan dan kesehatan kerja dan lingkungan kerja

2) Pelatihan first aid at work awareness/P3K

3) Pelatihan $5 \mathrm{~S} / 5 \mathrm{R}$

4) Pelatihan personal hygiene (kebersihan diri dalam bekerja)

5) Ergonomis saat bekerja

Adapun strategy lain dalam peningkatan potensi yang berhubungan dengan sosial dan masyarakat sebagai berikut:

1. Pemberdayaan UMKM sekitar

Melakukan bimbingan manajemen usaha masyarakat kecil menengah meliputi alur produksi dan manajemen keuangan

2. Pemberdayaan peran PKK

Membantu peranan PKK dalam melakukan efektifitas program dan efektifitasnya

3. Peningkatan Produktivitas

Memberikan pelatihan dan monitoring hasil dari produktifitas sebuah usaha maupun soft skill yang berhubungan dengan pola pikir yang produktif

4. Bibit Kehidupan/Green Global

Mengelola lahan kosong menjadi lebih produktif untuk penanaman kebutuhan dan proteksi pemanasan global

5. Village branding

Membantu dalam meningkatkan citra yang menonjolkan kelebihan sebuah daerah.

6. Soft skill "Potensi generasi 4.0"

Pengembangan diri dalam beradaptasi di lingkungan organisasi pada era 4.0

\section{$\underline{\text { Kesimpulan }}$}

Adapun hasil yang dapat disimpukan bahwa Desa Burangkeng merupakan desa tempat pembuangan sampah akhir yang perlu perhatian ekstra dari pemerintah, terutama pada aspek kesehatan masyarakat dan kondisi lingkungan. Adanya organisasi Prabu sebagai pemersatu warga belum dapat diperankan secara maksimal terutama jika berhubungan dengan kebijakan pemerintah, meskipun mereka telah berupaya untuk menjadi jembatan aspirasi, sebagai referensi akan informasi serta pengetahuan warga mengenai kondisi lingkungan serta dampak dari TPA. Pengelola TPA masih belum dapat menggunakan tekhnologi briket yang tertahan pada proposal persetujuan, strategy yang direncanakan oleh warga melalui organisasi Prabu berorientasi terhadap K3L dan pemberdayaan masyarakat sosial namun itu masih memerlukan dukungan dalam implementasinya. 


\section{Daftar Pustaka}

Basrowi, S. (2008). Memahami penelitian kualitatif. Jakarta: Rineka Cipta, 12(1), 128-215. BPS. (2020). Indeks Pembangunan Manusia (IPM) Indonesia pada tahun 2020 mencapai 71,94 Badan Pusat Statistik. https://www.bps.go.id/pressrelease/2020/12/15/1758/indeks-pembangunan-manusia-ipm--indonesia-pada-tahun-2020-mencapai-71-94.html

Denzin, N. K., \& Lincoln, Y. S. (2009). Handbook of Qualitative Research (terj.). Yogyakarta: Pustaka Pelajar.

Setyawati, D. (2008). Arahan Pemanfaatan Kembali Tempat Pembuangan Akhir (TPA) Sampah (Studi Kasus: TPA Putri Cempo, Kota Surakarta). Universitas Diponegoro.

Soemirat, J. (2006). Kesehatan Lingkungan. UGM Press.

Suliswanto, M. S. W. (2010). Pengaruh produk domestik bruto (PDB) dan indeks pembangunan manusia (IPM) terhadap angka kemiskinan di Indonesia. Jurnal Ekonomi Pembangunan, 8(2), 357-366.

Sutrisno, E. (2009). Manajemen Sumber Daya Manusia, edisi pertama, cetakan pertama. Penerbit: Kencana Pranada Media Group. Jakarta.

Yuniarti, T., \& Samariansyah, I. (2014). Peran Komunikasi Korporat Pengembang Kawasan Industri di Kabupaten Bekasi dalam Meredam Konflik Sosial Masyarakat. Makna: Jurnal Kajian Komunikasi, Bahasa, Dan Budaya, 5(1), 1-10. 